\title{
Renal vein leiomyosarcoma and renal cell carcinoma presenting together: A case report and discussion on the follow-up
}

\author{
Conor M. Devlin, MD; Kanwar Gill, MD; Jennifer Thomas, MD; Chandra Shekhar Biyani, MD
}

St. James's University Hospital, Beckett Street, Leeds, UK; Pinderfields General Hospital, Aberford Road, Wakefield, West Yorkshire, UK

Cite as: Can Urol Assoc J 2015;9(7-8):E517-20. http://dx.doi.org/10.5489/cuai.2846 Published online July 17, 2015.

\section{Abstract}

Leiomyosarcoma affecting the renal vein is rare, with about 30 documented cases in the English literature. The appearance on computed tomography can be difficult to interpret and is often confused with advanced renal cell carcinoma (RCC). This confusion can have implications on the perioperative care of patients presenting with this disease. We report a case with an usual radiological appearance of a renal vein leiomyosarcoma, alongside a separate RCC. This case highlights the need for a high index of suspicion in radiological reporting and provides a dilemma in regards to postoperative surveillance.

\section{Introduction}

Primary leiomyosarcoma in a vein is a rare presentation, with over half usually arising from the inferior vena cava. ${ }^{1}$ Leiomyosarcoma arising from a renal vein is very uncommon with around 30 cases reported in the literature. ${ }^{2-4}$ Patients can present with a range of symptoms from flank pain, to weight loss or fatigue. ${ }^{5} \mathrm{~A}$ range of renal diseases can produce these symptoms and as such the preferred imaging modality is often computed tomography $(\mathrm{CT})$. It can be difficult to correctly diagnose renal vein leiomyosacroma on $\mathrm{CT}$, often reported as a renal cell carcinoma (RCC) with venous extension. ${ }^{5}$

We report a case of a suggested a right RCC adjacent to the renal vein on CT. Histology confirmed the presence of three separate tumours: a renal vein leiomyosarcoma, a RCC, and an adrenal adenoma. To date, no similar cases have been reported.

\section{Case report}

A 68-year-old male with known chronic obstructive pulmonary disease presented to respiratory physicians with hemoptysis. A CT scan of the chest and abdomen showed an incidental 19-mm nodule adjacent to the right renal vein, which was reported as a likely RCC (Fig. 1). A benign right adrenal adenoma was also reported. The images were reviewed at the urological multidisciplinary team, with a consensus reached to manage with active surveillance.

A repeat CT at 6 months demonstrated the suspicious nodule had increased in size to $21 \mathrm{~mm}$ and enhanced following administration of contrast (Fig. 2). It had an exophytic appearance, but still suggested RCC. The images were reviewed at the regional oncology centre and clinicians concluded the lesion mostly represented a RCC. The patient was offered surgical removal, but he declined however agreed to have re-imaging after 4 months.

The subsequent CT scan and positron emission tomography (PET) scan showed the nodule had increased in size to $30 \mathrm{~mm}$ and was still suggestive of a RCC (Fig. 3). The patient consented to a laparoscopic right nephrectomy in view of the location of the mass. The formal histology report concluded the area of concern marked from the CT was a spindle cell lesion without tissue necrosis representing a grade 2 leiomyosarcoma (Fig. 4). In addition a separate focus in the kidney contained a small cystic RCC (Fig. 5). The adrenal mass appeared to be a cortical adenoma on histology.

The patient was discussed at the regional sarcoma multidisciplinary team, the resection margins were clear and the patient did not require any further interventions. A plan of 6 monthly CT scans was agreed upon for surveillance and he was disease-free at the 12-month follow-up.

\section{Discussion}

Leiomyosarcoma accounts for $5 \%$ to $10 \%$ of soft tissue sarcomas, with about half of these originating in the inferior vena cava. ${ }^{3}$ From the very small number of published cases, it more commonly occurs in females (83\%) and has a higher incidence on the left side $(60 \%){ }^{3}$ Our case report offers a different story.

It has been documented that the radiological diagnosis of renal vein leiomyosarcoma is difficult, ${ }^{5,6}$ sometimes 


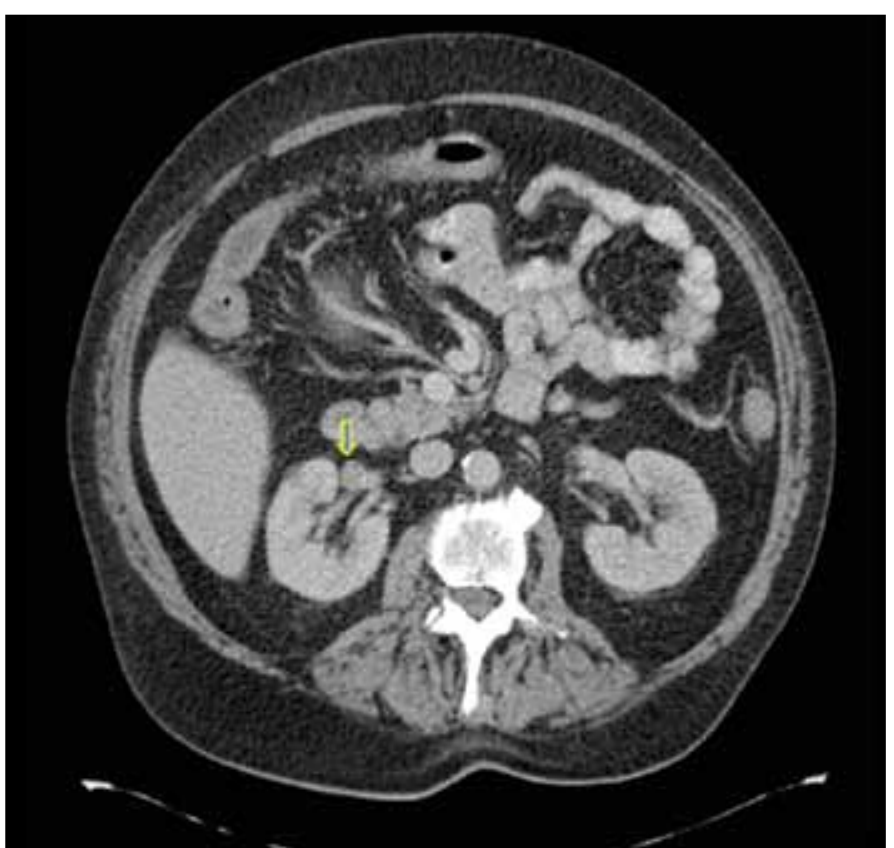

Fig. 1. Enhanced computed tomography of the abdomen showed a $19 \mathrm{~mm}$ nodule lying adjacent to the right renal vein.

being mistaken for advanced RCC with venous extension. ${ }^{5}$ Kaushik described the typical CT appearance as a homogenous, well-circumcised solid mass with minimal contrast enhancement in the region of the renal hilum, ${ }^{7}$ as seen in our case. Recently Maturen and colleagues reviewed the radiological imaging for 5 cases of renal vein leiomyosarcoma. They reported that in all cases the intravascular component

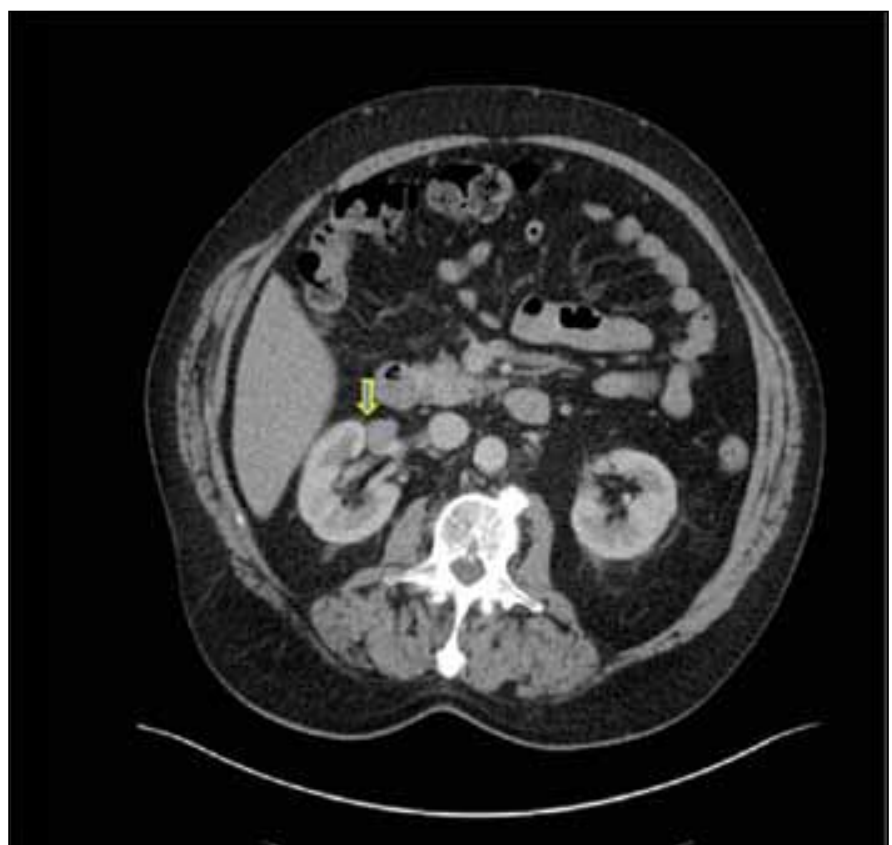

Fig. 2. A 6-month scan demonstrated increase in size to $21 \mathrm{~mm}$.

of the tumour was larger than the intrarenal component. ${ }^{5}$ In our case, however, the tumour was reported as an exophytic mass arising immediately adjacent to the renal vein. There was no reported intravascular extension or "invasion." The tumour was therefore reported as a RCC, thus highlighting the difficulty of radiological diagnosis and also the uniqueness of our case.

Table 1: Published cases of leiomyosarcoma

\begin{tabular}{|c|c|c|c|c|}
\hline Age/sex & Presentation & Imaging and report & Surgery & Follow-up \\
\hline $77 \mathrm{~F}$ & Flank pain and fatigue & CT - suggested RCC & $\begin{array}{l}\text { Left radical } \\
\text { nephrectomy }\end{array}$ & $\begin{array}{l}\text { Chemotherapy - no } \\
\text { recurrence }^{5}\end{array}$ \\
\hline $62 \mathrm{~F}$ & $\begin{array}{l}\text { Massive pulmonary } \\
\text { embolism }\end{array}$ & $\mathrm{CT}$ - suggested RCC & $\begin{array}{l}\text { Left radical } \\
\text { nephrectomy }\end{array}$ & $\begin{array}{l}\text { Chemotherapy - no } \\
\text { recurrence }\end{array}$ \\
\hline $43 \mathrm{M}$ & $\begin{array}{l}\text { Thirst, weight loss and } \\
\text { hypertension }\end{array}$ & CT - suggested lymphoma & $\begin{array}{l}\text { Left radical } \\
\text { nephrectomy }\end{array}$ & $\begin{array}{l}\text { Chemotherapy - no } \\
\text { recurrence }^{5}\end{array}$ \\
\hline $69 \mathrm{M}$ & Flank pain & CT - suggested Lymphoma & $\begin{array}{l}\text { Right radical } \\
\text { nephrectomy }\end{array}$ & $\begin{array}{l}\text { Chemotherapy - no } \\
\text { recurrence }{ }^{5}\end{array}$ \\
\hline $42 \mathrm{M}$ & Abdominal pain & $\begin{array}{c}\text { CT - suggested retroperitoneal } \\
\text { sarcoma }\end{array}$ & $\begin{array}{l}\text { Left radical } \\
\text { nephrectomy }\end{array}$ & $\begin{array}{c}\text { Chemotherapy - recurrence, } \\
\text { still alive }^{5}\end{array}$ \\
\hline $67 \mathrm{~F}$ & $\begin{array}{l}\text { Incidental finding CT for } \\
\text { diabetes follow up }\end{array}$ & CT - suggested sarcoma & $\begin{array}{l}\text { Right radical } \\
\text { nephrectomy }\end{array}$ & $\begin{array}{c}\text { No chemotherapy, } 6 \text { monthly } \\
\text { CT - no recurrence }{ }^{4}\end{array}$ \\
\hline $47 \mathrm{M}$ & Mass in flank & $\begin{array}{l}\text { USS - mass not related to renal } \\
\text { parenchyma, close to the renal vein }\end{array}$ & $\begin{array}{l}\text { Left radical } \\
\text { nephrectomy }\end{array}$ & No chemotherapy ${ }^{15}$ \\
\hline $43 \mathrm{~F}$ & $\begin{array}{l}\text { Found on investigation } \\
\text { for back pain }\end{array}$ & $\mathrm{CT}$ - retroperitoneal sarcoma & $\begin{array}{l}\text { Left radical } \\
\text { nephrectomy }\end{array}$ & $\begin{array}{l}\text { No chemotherapy - CT } 6 \\
\text { monthly - no recurrence }\end{array}$ \\
\hline $43 \mathrm{~F}$ & $\begin{array}{l}\text { Left-sided abdominal } \\
\text { pain }\end{array}$ & $\begin{array}{l}\text { CT - mass, possibly } \\
\text { pheochromocytoma }\end{array}$ & $\begin{array}{l}\text { Left radical } \\
\text { nephrectomy }\end{array}$ & $\begin{array}{l}\text { No chemotherapy - CT } 6 \\
\text { months - no recurrence }{ }^{16}\end{array}$ \\
\hline $\begin{array}{l}68 \mathrm{M} \\
\text { (current case) }\end{array}$ & $\begin{array}{l}\text { Incidental finding on CT } \\
\text { for chest symptoms }\end{array}$ & $\begin{array}{c}\mathrm{CT} \text { - suggested } \mathrm{RCC} \text { next to renal } \\
\text { vein }\end{array}$ & $\begin{array}{l}\text { Right radical } \\
\text { nephrectomy }\end{array}$ & $\begin{array}{l}\text { No chemotherapy }-12 \\
\text { months } \mathrm{CT}-\text { no recurrence }\end{array}$ \\
\hline
\end{tabular}



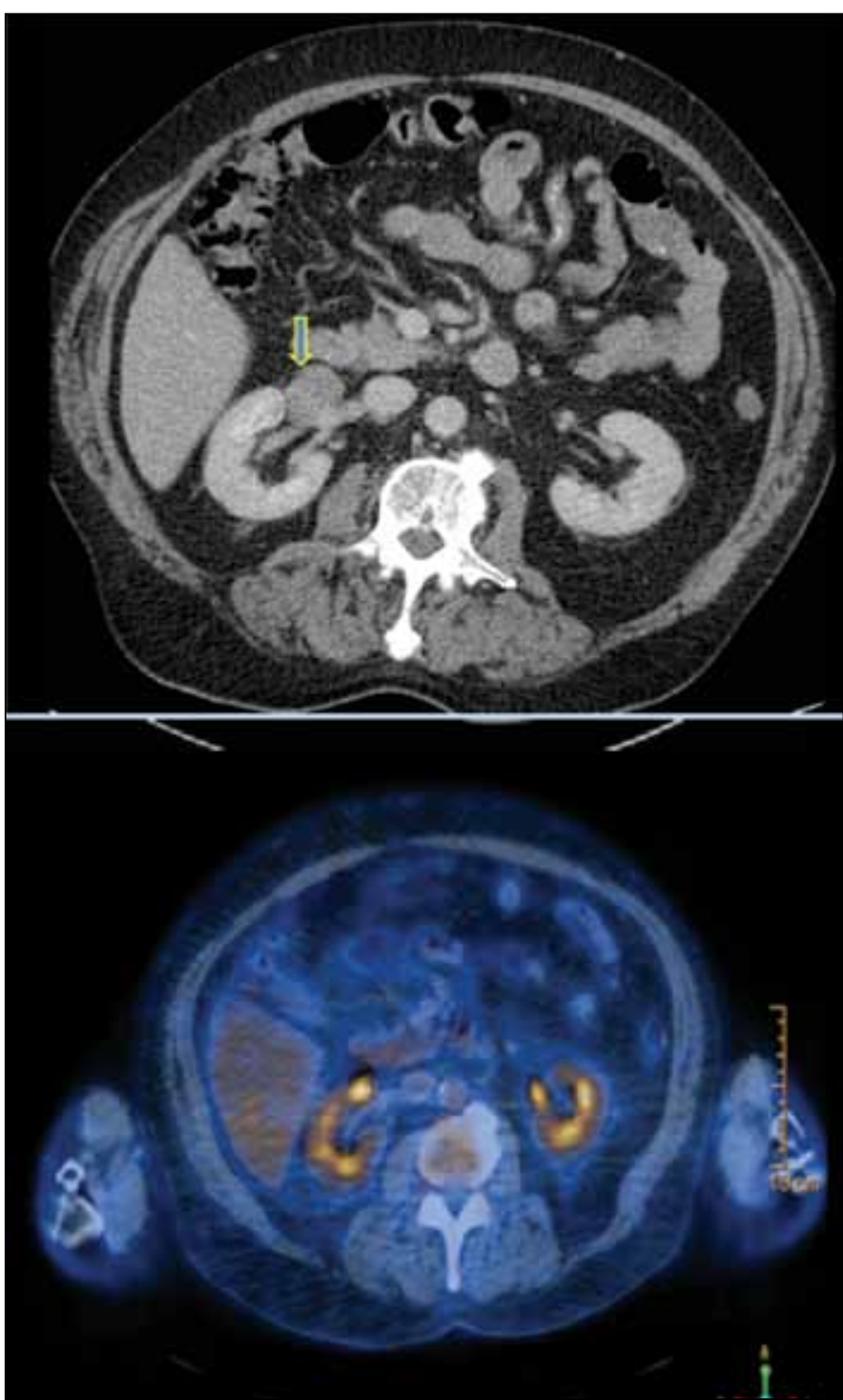

Fig. 3. A 12-month CT (upper) and PET (lower) scan revealed an increase in the size to $30 \mathrm{~mm}$.

The role of neoadjuvant therapy is important in cases of retroperitoneal sarcoma, ${ }^{8}$ but rarely RCC. ${ }^{9}$ However, with the small number of reported cases, there is little evidence that chemo/radiotherapy is effective in renal vein leiomyosarcoma. ${ }^{10,11}$ The uncertainty of the diagnosis in our case made choosing the correct perioperative management plan difficult, highlighting an area that may potentially affect other similar cases.

The fact our case has two separate malignancies presenting together is interesting in this field and not reported before. The issue of the most appropriate follow-up regimen has led to a large amount of multidisciplinary team discussion. In regards to RCC follow-up, the European Association of Urology guidelines state radiological follow-up is dependent on the risk category, influencing the time line for chest

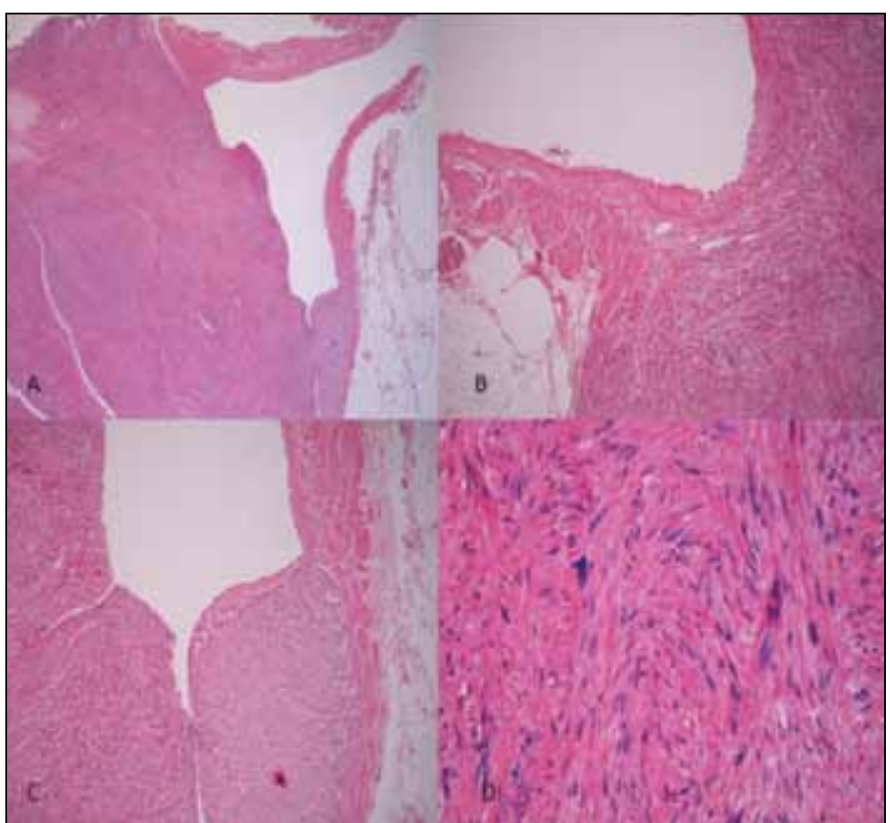

Fig. 4. The microscopy showed solid nodular tumour within the renal vein [hematoxylin-eosin $x 1.25(A)$ and $\times 5(B, C)$ ]. The spindle cells are organised in well-defined bundles and contain abundant mitotic figures with areas of hyalinisation (x $20 \mathrm{D})$.

radiography and/or CT thorax/abdomen investgations. ${ }^{12}$ The follow-up for retroperitoneal sarcoma normally includes CT investigations every 3 to 6 months for 2 to 3 years. ${ }^{13}$ The consensus for our case was to adhere to the regimen relevant to the tumour with the highest risk: in this case the renal vein leiomyosarcoma. We feel this process can be adopted if future cases similar to ours present themselves.

A review of investigation, treatment and follow-up published cases in the last 11 years is summarized in Table 1 . The important observation is that all cases were radio-

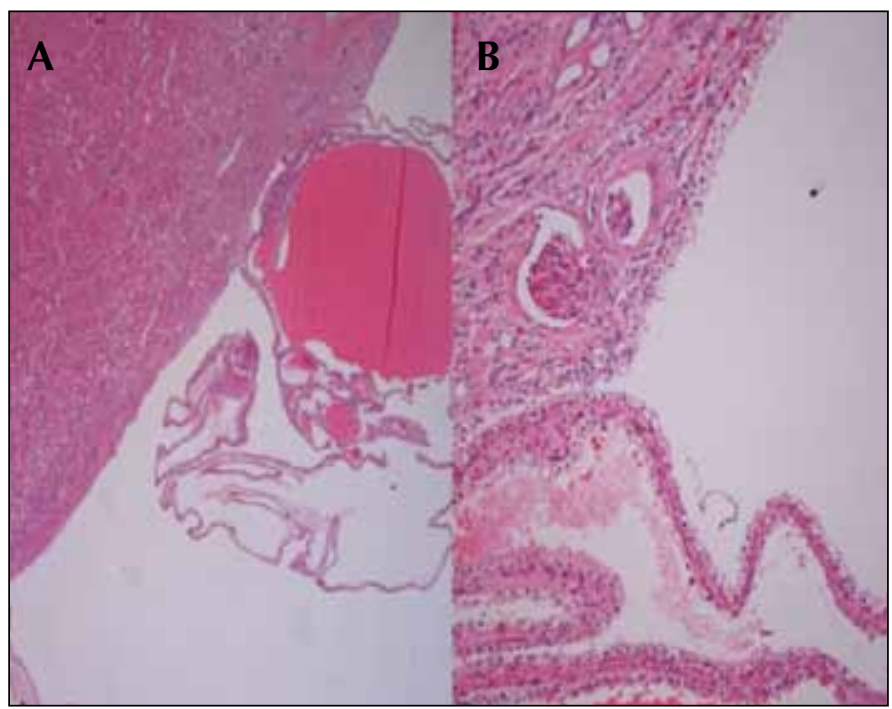

Fig. 5. A coincidental renal cell cystic carcinoma $[H \& E, x 1.25(A), x 10(B)]$. 
Biyani et al.

logically reported different from leiomyosarcoma. The most common surveillance was 6 monthly CT scans.

\section{Conclusion}

The presentation of renal vein leiomyosarcoma still remains a rare event. Radiological diagnosis can be difficult, potentially affecting the perioperative care of a patient. A high index of suspicion must be held for unusual radiological appearances of renal tumours. Our case has demonstrated that two separate tumours can exist together and a logical and evidence based follow-up regimen must be agreed upon.

Competing interests: The authors all declare no competing financial or personal interests.

This paper has been peer-reviewed.

\section{References}

1. Kevorkian J, Cento CP. Leiomyosarcoma of large arteries and veins. Surgery 1973; 73: 390-400.

2. Lipton $M$, Sprayegen $S$, Kutcher $R$, Frost A. Venous invasion in renal vein leiomyosarcoma: case report and review of the literature. Abdom Imaging 1995;20:64-7. http://dx.doi.org/10.1007/BF00199648

3. Aguilar I, Benavente V, Pow Sang M. Leiomyosarcoma of the renal vein: case report and review of the literature. Urol Oncol 2005;23:22-6. http://dx.doi.org/10.1016/i.urolonc.2004.06.004
4. Maeda $\mathrm{T}$, Tateishi $\mathrm{U}$, Fujimoto $\mathrm{H}$, et al. Leiomyosarcoma of the renal vein: arterial encasement on contrast dynamic computed tomography. Int J Urol 2006;13:611-12. http://dx.doi.org/10.1016/i. urolonc.2004.06.004

5. Maturen KE, Vikram R, Wu AJ, Francis IR. Renal vein leiomyosarcoma and clinical features of a renal cell carcinoma mimic. Abdom Imaging 2013;38: 379-87. http://dx.doi.org/10.1007/s00261-012-9888-0

6. Imao T, Amano T, Takemae K. Leiomyosarcoma of the renal vein. Int I Clin Oncol 2011;16:76-79. http://dx.doi.org/10.1007/s10147-010-0115-0

7. Kaushik S, Neifeld JP. Leiomyosarcoma of renal vein: imaging and surgical reconstruction. Am J Roentgenol 2002;179:276-7. http://dx.doi.org/10.2214/air.179.1.1790276

8. Hines $0 \mathrm{OJ}$, Nelson S, Quinones-Baldrich WJ, Eilber FR. Leiomyosarcoma of the inferior vena cava: prognosis and comparison with leiomyosacroma of other anatomic sites. Cancer 1999;85:1077-1083. http:// dx.doi.org/10.1002/(SICI) 1097-0142(19990301)85:5<1077::AID-CNCR10>3.0.C0;2-0

9. Homicsko K, Berthold DR. Neoadjuvant and adjuvant strategies in renal cell carcinoma: more questions than answers. Anticancer Drugs, 2011;22(Suppl1):S4-8. http://dx.doi.org/10.1097/01. cad.0000390766.47540.07

10. Mingoli A, Cavallaro A, Sapienza P eta I. international registry of inferior vena cava leiomyosarcoma: analysis of a world series on 218 patients. Anticancer Res, 1996;16:3201-6.

11. Hollenbeck ST, Grobmyer SR, Kent KC et al. Surgical treatment and outcomes of patients with primary inferior vena cava leiomyosarcoma. J Am Coll Surg 2003;197:575-9. http://dx.doi.org/10.1016/ S1072-7515(03)00433-2

12. Liunberg $B$, cowan $N C$, Hanbury $D C$ et al. European Association of Urology guideline group EAU guidelines on renal cell carcinoma: the 2010 update. Eur Urol 2010;58:398-406.

13. Mullen JT, Delaney TF. Clinical features, evaluation and treatment of retroperitoneal soft tissue sarcoma. Ann Surg Oncol 2012;19:511. http://dx.doi.org/10.1016/i.eururo.2010.06.032

Correspondence: Mr. Chandra Shekhar Biyani, Consultant Urologist, Department of Urology, St James's University Hospital, Leeds Teaching Hospitals NHS Trust, Beckett Street, Leeds, West Yorkshire LS9 7TF, UK; shekharbiyani@hotmail.com 